\title{
Effect of Cooperative Teaching Method on Senior Secondary School Students' Achievement and Retention in Financial Accounting in Enugu State
}

\author{
Emeka Promise Ugwunwoti, Ph.D \\ Department Of Business Education, Enugu State University of Science And Technology
}

\begin{abstract}
This study empirically investigated the effect of Cooperative teaching Method on Senior Secondary School Students' Achievement and Retention in Financial Accounting in Enugu State. Four research questions and six hypotheses guided the study. Pretest-posttest non-randomized control group design was adopted for the study. The study was conducted in Agbani Education zone of Enugu State. The population for the study consisted of all co-educational senior secondary school one students who are offering Financial Accounting in Agbani Educational Zone of Enugu State numbering 300 whereas a sample of 165; 110 females and 55 males senior secondary school one students were drawn from (two intact classes). The cooperative group (experimental) consisted of 30 males and 85 females group totally 115 and 15 males and 30 females for controlled group. Techniques adopted for sampling was purposive multislage random sampling. Instrument used for data collection was Financial Accounting Achievement Test (FAAT) consisting of 60 item quwstions adopted from past WAEC and NECO question papers. The instrument was face and content validated by three experts. The instrument used was further tested on 20 senior secondary school one students similar to those used for the study in another Educational Zone. The researcher adopted the Kuder Richardson Formula (K-R20) in determining the pre-FAAT and post-FAAT hence yielded reliability coefficient of 0.68 . Mean and standard deviation was used in answering research questions. Hypotheses were tested using Analysis of Covariance (ANCOVA) at 0.05 level of significance. The study revealed that the experimental group (cooperative group) achieved higher and retained more Financial Accounting than their counterparts in the control group. Also male and female students did not differ significantly in their achievement and retention in Financial Accounting. It was recommended that cooperative method should be used in teaching financial Accounting. Again, financial Accounting teachers should be encouraged to embark on regular training and retraining on the effective use of cooperative learning in the classroom.
\end{abstract}

Keywords: Financial Accounting, Cooperative method, Secondary School, Achievement and Retention.

DOI: $10.7176 / \mathrm{JEP} / 12-27-13$

Publication date:September $30^{\text {th }} 2021$

\section{Introduction}

One of the components of level of institutions in Nigeria is secondary school. Secondary school may be seen as a type of school established for the continuation of teaching and learning activities by students after primary school.

Anieke and Nwankwegu (2019), stated that secondary school equips the learners with the background knowledge of basic arts and science related subjects for transition into tertiary institutions. However, secondary school is where secondary education is obtained. According to the Federal Republic of Nigeria (2014), secondary education is a level of education where children receive education after primary education and before the tertiary stage. In secondary school there are junior and senior classes respectively.

Senior secondary schools are the next stage after upper Basic Education three (ugwunwoti and Onah, 2020). Secondary school is made up of three components (Senior secondary school one to three, SSI-3). In senior secondary schools various subjects are offered including financial accounting.

Financial accounting according to Ugwunwoti and Onah, (2020) is the process of collecting, recording, presenting and analyzing, interpreting financial statements. Financial Accounting is offered as one of the elective subjects in senior secondary schools. According to Federal Republic of Nigeria (2008), Financial Accounting curriculum is designed to meet the following objectives; to provide specialized instruction to prepare students for career in the accounting fields; provide accounting skills for personal use in the future; enable the senior secondary school candidate appreciates the basic rules, functions and principles of accounting; assess candidate's knowledge of basic accounting principles practice and their application to modern business activities. The above 
objectives can be achieved if effective appropriate teaching method like corporative method is adopted by teachers.

Cooperative learning is a successful teaching strategy in which small teams, each with students of different levels of ability, use variety of learning activities to improve their understanding of a subject to improve their understanding of a subject. Johnson and Johnson (2013) saw cooperative teaching method as an active educative strategy with small groups in order that the students will develop the learning of both themselves and the group members. In order word, cooperative entails an amount of togetherness of idea and goal.

Contributing, Emesoba (2018) opined that, in the course of study under the cooperative method, the individual student indicate an effort that supports the learning of both herself and her companions. Based on this, cooperative teaching method involves small group of students working collaboratively on classroom projects. Apart from this, the students in a group learn the same course, work together and share responsibility and teachers as guides, facilitators and senior partners, not as dispenser of knowledge.

Moreover, Oyidiya (2010), pointed out that cooperative learning points with other elements of an effective classroom because cooperative activities pair students together (student-centered). Students' interests are addressed through thematic planning (thematic addressed). Cooperative activities naturally get students up to interact with their environment paired and group activities offer excellent opportunities for teachers to model specific methods (cognitive apprenticeship).

Cooperative teaching method will promote among financial accounting students the ability and the inclination to work together beyond the classroom by taking cooperation not just part of the learning process but also part of the content. Although, one of the greatest challenges of cooperative teaching is its reliance on a positive group dynamic, to function at its highest efficiency (Browyn 2017). Despite those challenges cooperative method, is better than traditional method,

In traditional method, students participation are minimal and they are not given opportunity to give feedback to the teacher and of course method has been widely reported in supporting, academic achievement or low performing students (Okoro 2011). On the other hand, traditional method is a "one-way traffic" type of classroom interaction in which the teacher talks and writes note on the board while the students listen and copy down notes.

In this study, cooperative method is the experimental group while other is traditional method. Hence, there is need to investigate the academic achievement and retention of students in financial accounting.

Retention is the action of absorbing and continuing to hold a substance. Retention implies one's ability to remember things. Accounting to Harb (2016), retention of learning is measured with two tests. The "initial test" and the delayed retention test". Initial or the pre-test is the one used at the time of the instrument or immediately thereafter. Delayed or post-test are those administered two or more weeks after the initial testing to measure knowledge.

Meanwhile, students' academic achievement is a notable change in the students' performance as a result of their exposure to specific programmes of instruction. According to Amadike (2014), achievement is an attained success in any given success in learning specific curriculum content. Therefore achievement is concerned with the ability to perform with adequacy and excellence when measured against specific standard of attainment. Retention and achievement in financial accounting depends on various topics taught.

In financial accounting, various topics are taught in senior secondary school one (SSS1). However, for this study, the following topics were considered VIZ: Journals, Bank reconciliation statement, Control accounts, Trading, Profit and loss accounts and Balance sheet of a sole trader.

Journal is one of the financial accounting topics taught in SSS1. Journals are the prime books of original entry (Okpe,2015). At the end of the teaching irrespective of the method, students should be able to define journal, state the classes of journal, show its formats and post entries.

Bank reconciliation statement is also a financial accounting topic taught in senior secondary school one. It is a periodical statement prepared to make the entries in the bank account of an organization agree with the entries made by its bank in respect of its transaction with the bank (Ubesie 2008). Students are expected to identify causes of disagreement between cash book balance and bank balance, prepare and balance adjusted cash book and Bank reconciliation statement. 
Control account is the summary of individual debtors and creditors accounts in sales and purchases ledger. According to Ibrahim and Kazeem (2015), it is the account to which is debited and credited the total amounts of all the transactions which have been debited and credited in details to individual debtors and creditors ledgers

Trading, profit and loss accounts and balance sheet are regarded as final accounts. Trading accounts shows either gross profit or gross loss while profit and loss accounts shows either Net profit or loss. Balance sheet is not an accounts but a statement showing assets and liabilities as a period date (Okpe 2015). These topics are taught in all education zones in Enugu state.

Enugu state is one of five states in southern part of Nigeria. There are six education zones in Enugu state. However, this study was carried out in Agbani Education Zone.

Despite the crucial role accounting play in national development, the achievement and retention in the subject area at senior secondary school level is not encouraging. Base on the experience of the teachers in teaching accounting over the years, students poor academic performance in financial accounting can be linked to the teaching methods by the teachers. Result analysis by the West African Examination Council (2019), showed that the financial accounting recorded 58.2 percent, 51 percent and 50.1 percent failure, in 2017, 2018 and 2019 respectively. This poor performance has been of a great concern to the stakeholders of the subject.

Could it be that this poor performance may be as a result of teaching method adopted by the teachers. In an attempt to answer this question, gave raise to carrying out this work on effect of cooperative teaching method on financial accounting on senior secondary schools (SSS1) students achievement and retention in Financial Accounting in Agbani Education Zone of Enugu state.

Apart from teaching method employed by teachers in teaching financial accounting, gender is another variable to be considered. Accounting to Abdul-Raheem (2010), gender involves the roles, attitudes, behaviour and values. Agboola (2019) opined that male students experience less anxiety about the use of modern technology skills than female students. This is in contrast with the study of Simsek, Yular and Kikuk (2013), that gender has on effect on the influence of the cooperative teaching method on academic achievement of students. Therefore an investigation of gender influence in this research will shade more light on the issue of the financial accounting in Agbani Education Zone.

\section{Statement of the Problem}

Financial accounting is one of the selective subjects offered in Nigerian senior secondary schools. Financial accounting at this level is offered to lay proper foundation for further study of accounting and allied courses at higher level.

Despite the crucial role financial accounting plays in national development, the achievement and retention in the subject area at secondary school level is not encouraging. Research evidence has confirmed student's persistent poor performance in financial accounting in external examinations. Again research has shown the poor enrollment of the subject by the students.

This may be attributed to many factors. Could it be that financial accounting teachers employ only traditional methods of teaching instead of innovative methods like cooperative method? If the study centered learning styles are accommodated, it may result to positive attitudes towards learning and consequently increase in retention and academic achievement.

The problem of the study put in a question form is "what are the effects of cooperative teaching method on senior secondary school student's achievement and retention in financial accounting in Enugu State.

\section{Purpose of the Study}

The main purpose of this study was to investigate the effect of cooperative teaching method on Financial Accounting on senior secondary school (SSS1) student's achievement and retention in Financial Accounting in Enugu State.

Specially; the study sought to:

1. determine the Financial Accounting mean achievement scores of SSS1 students in the experimental (cooperative) and control groups in both pretest and posttest; 
2. determine the Financial Accounting mean retention $m$ scores of SSS1 students in the experimental (cooperative) and control groups;

3. determine the Financial Accounting mean achievement scores of male and female SSS1 in the cooperative and control groups in both pretest and posttest;

4. determine the financial accounting mean retention scores of male and female SS1students in the cooperative and control groups.

\section{Research Questions}

The following research questions were tested at 0.5 level of Significance

1. What are the Financial Accounting mean achievements scores of SSS1 students in the experimental (cooperative) and control groups in both pretest and posttest?

2. What are the Financial Accounting mean retention scores of SSS1 students in the cooperative and control group?

3. What are the Financial Accounting mean achievement scores of male and female of SSS1 students in the cooperative and control group in both pretest and posttest?

4. What are the mean Financial Accounting mean retention scores of male and female SSS1 students in cooperative and control group?

\section{Hypotheses}

The following research hypotheses were tested at 0.5 level of significance.

Ho1: There is no significant difference between the Financial Accounting mean achievements scores of SSS1 students in the experimental (cooperative) and control groups.

Ho2: There is no significant difference between the Financial Accounting mean retention scores of the SSS1 students in experimental and control groups.

Ho3: There is no significant difference between the Financial Accounting mean achievement scores of male and female SSS1 students in the experimental and control groups.

Ho4: There is no significant difference between the Financial Accounting mean retention scores of male and female SSS1 students in the experimental and control groups.

Hos: There is no significant interaction between teaching method and students gender on SSS1 mean achievement scores in Financial Accounting

Ho6: There is no significant interaction between teaching method and students gender on SSS1 students mean retention scores in Financial Accounting.

\section{Method}

The design for the study was quasi- experimental design. Hence, the design was a prettest and posttest, non equivalent control group design. The area of the study was Agbani Education zone.

A sample size consisted of 165 financial accounting students in senior secondary school one (SSS1) in the zone. The sample also consisted of 55 males and 115 female. The sample was randomly drawn from two schools in the zone of the study.

Financial Accounting Achievement Test (FAAT) was used to collect achievement scores (pretest and posttest). A Reshuffled of FAAT version (printed in a different colour of paper) was also used to collect retention scores two-weeks after the posttest. FAAT was developed by the researcher. It has sixty (60) multiple choice questions with four options each. The items were drawn using a Table of specification to make sure that content area are covered and even maintain and spread across the different levels of the domain tested.

FAAT was validated (face and content) by three research experts; after vital corrections observed by the experts. 
FAAT was confirmed to have face and content validity. FAAT yielded a stability coefficient of 0.68 obtained using test-retest approach. FAAT also yielded a reliability coefficient of 0.69 using Kudar- Richardson 20 (KR20) formula.

\section{Experimental procedures}

The researcher trained three regular Financial Accounting teachers (research assistants) in the three secondary schools used for the study for the period of two weeks. They were trained on selected topics used in this study. FAAT was administered to all concerned of the study as pretest. Thereafter, the treatment was administered for a period of six weeks.

The experimental (cooperative) group in each school was taught the selected Financial Accounting topics using cooperative while the control group in each school was taught the same topics using discovery method. All topics were drawn from SSS1 financial accounting scheme of work.

At the end of the treatment period, the FAAT was re-arranged and administered to all the subjects as protest, FAAT was re-arranged and administered to all the subjects as retention test.

Mean and standard deviation was used to answer research question while analysis of covariance (ANCOVA) was used in testing hypotheses at .05 level of significance.

\section{Results:}

Research question one: What are the financial accounting mean achievement scores of SS1 Students in the experimental (cooperative) and control groups in both pretest and posttest?

Table 1: Financial Accounting mean achievement scores of SS1 Students in the experimental (cooperative) and control groups

\begin{tabular}{llll}
\hline GROUP & & PRETEST & POSTTEST \\
\hline Experimental & $\mathrm{N}$ & 115 & 115 \\
& Mean & 52.79 & 74.20 \\
Control & SD & 7.14 & 8.24 \\
& $\mathrm{~N}$ & 50 & 50 \\
& Mean & 48.96 & 56.88 \\
& SD & 5.63 & 7.40
\end{tabular}

The results in table 1 above indicate that the experimental group obtained a mean score of 52.79 and 74.20 respectively in their pretest and posttest with corresponding standard deviation of 7.14 and 8.24. On the other hand, the students in control group had the mean score of 48.96 and 56.88 respectively in their pretest and posttest with a corresponding standard deviation of 5.63 and 7.40. It was also revealed that the experimental group obtained a gain in mean score of 21.41 while the lecture method group had gain in mean score of 7.92. The difference in mean gain between students in experimental group and control group 13.49. This indicates that students in experimental group achieved higher than students in control group, hence, students taught financial accounting using cooperative teaching method performed better than their counterparts taught with lecture method. However, the standard deviation scores of the students in the post test for the experimental group was 8.24, while for the control group was 7.40 indicating that the student individual scores clusters around the mean in their respective groups.

Research question two: What are the financial accounting mean retention scores of SS1 students in the experimental (cooperative) and control groups? 
Table 2: Financial Accounting mean retention scores of SS1 Students in the experimental (cooperative) and control groups

\begin{tabular}{llll}
\hline GROUP & N & Mean & Std. Deviation \\
\hline Experimental & 115 & 61.95 & 7.01 \\
Control & 50 & 47.88 & 7.40
\end{tabular}

The results in table 2 shows that the students in the experimental group had mean retention score of 61.95 with the corresponding standard deviation of 7.01. While the students in control group had respective mean retention score and standard deviation score of 47.88 and 7.40. The students in the experimental group had higher mean retention score than their counterpart in control group. This shows that students taught Financial Accounting using cooperative method retain better than their counterpart taught using lecture method.

Research question three: What are the financial accounting mean achievement scores of male and female SS1 Students in the experimental (cooperative) and control groups in both pretest and posttest?

Table 3: Financial Accounting mean achievement scores of male and female SS1 Students in the experimental (cooperative) and control groups

\begin{tabular}{lllll}
\hline GROUP & & & PRETEST & POSTTEST \\
\hline Experimental & Male & N & 30 & 30 \\
& & Mean & 52.57 & 74.97 \\
& Female & SD & 6.96 & 7.35 \\
& & 85 & 85 \\
Control & Mean & 52.87 & 73.93 \\
& Male & SD & 7.24 & 8.56 \\
& N & 15 & 15 \\
& & Mean & 49.60 & 58.27 \\
& SD & 4.78 & 7.98 \\
& Female & N & 35 & 35 \\
& & Mean & 48.69 & 56.29 \\
& SD & 6.00 & 7.17 \\
\hline
\end{tabular}

Table 3 shows that male students in the experimental group had mean achievement of 52.57 for pretest and 74.97 for posttest with respective standard deviation scores of 6.96 and 7.35. Likewise, the female students in experimental group had mean achievement scores of 52.87 for pretest and 73.93 for posttest with their standard deviation scores of 7.24 and 8.56. It was also revealed that the students in control group had pretest scores of 49.60 for male and 48.69 for female with their respective standard deviation scores of 4.78 and 6.00 . In posttest score, the male students obtained 58.27 mean score with standard deviation score of 7.98 , whereas their female counterpart obtained mean score of 56.29 with standard deviation score of 7.17. However, the male students (74.97) in the experimental group slightly achieved higher than their female (73.93) counterpart, but the difference wasn't significant. Although, the standard deviation scores for male (7.35) and female (8.56) students in the experimental group, indicates that the male students' scores were more clustered around the mean than their female counterpart.

Research question four: What are the Financial Accounting mean retention scores of male and female SS1 students in experimental (cooperative) and control groups? 
Table 4: Financial Accounting mean retention scores of male and female SS1 Students in the experimental (cooperative) and control groups.

\begin{tabular}{lllll}
\hline GROUP & & N & Mean & SD \\
\hline Experimental & Male & 30 & 64.00 & 6.49 \\
\multirow{2}{*}{ Control } & Female & 85 & 61.22 & 7.08 \\
& Male & 15 & 49.27 & 7.98 \\
& Female & 35 & 47.29 & 7.17 \\
\hline
\end{tabular}

The results in table 4 show that the male students in both experimental and control groups had mean retention score of 64.00 and 49.27 respectively with respective standard deviation scores of 6.49 and 7.98. Similarly, the female students in both experimental and control groups had mean retention scores of 61.22 and 47.29 respectively with the corresponding standard deviation scores of 7.08 and 7.17 .

In the experimental group, the male students (64.00) retains better than their female counterpart (61.22), also the standard deviation scores for male (6.49) and female (7.08) students indicates that the male students' scores were more clustered around the mean than their female counterpart. Hence, male students taught financial accounting using cooperative method retain better than their female counterpart taught using the same method.

Table 5: Analysis of Covariance of financial accounting mean achievement scores of male and female students in experimental and control groups

\begin{tabular}{lcccccc}
\hline Source & $\begin{array}{c}\text { Type III Sum } \\
\text { of Squares }\end{array}$ & df & Mean Square & F & Sig. & Dec. \\
\hline Corrected Model & $10518.993^{\mathrm{a}}$ & 3 & 3506.331 & 54.466 & .000 & \\
Intercept & 494563.222 & 1 & 494563.222 & 7682.354 & .000 & \\
Group & 8404.746 & 1 & 8404.746 & 130.556 & .000 & S \\
Gender & 64.913 & 1 & 64.913 & 1.008 & .317 & NS \\
Group * & 6.346 & 1 & 6.346 & .099 & .754 & NS \\
Gender & 10364.619 & 161 & 64.377 & & & \\
Error & 805345.000 & 165 & & & & \\
Total & 20883.612 & 164 & & & & \\
Corrected Total & & & & & \\
a. R Squared = .504 (Adjusted R Squared =.494) & & & & & \\
\hline
\end{tabular}

Hypothesis one: There is no significant difference between the financial accounting mean achievement scores of SS1 students in the experimental group (cooperative) and control groups.

Table 5 shows that the F-value on financial accounting mean achievement scores of SS1 students in the experimental group (cooperative) and control groups is 130.56 which is significant at 0.000 level of significance, which is less than 0.05 level of significance set for the study. Therefore, the null hypothesis is rejected; this means that there is a significant difference between the financial accounting mean achievement scores of SS1 students in the experimental group (cooperative) and control groups.

Hypothesis three: There is no significant difference between the financial accounting mean achievement scores of male and femaleSS1 students in the experimental group (cooperative) and control groups.

Table 5 shows that the F-value on financial accounting mean achievement scores of male and femaleSS1 students in the experimental group (cooperative) and control groups is 1.008 which is not significance at 0.317 level of significance, which is greater than 0.05 level of significant set for the study. Therefore, the null hypothesis is not rejected; this means that there is no significant difference between the financial accounting mean achievement scores of male and female SS1 students in the experimental group (cooperative) and control groups.

Hypothesis five: There is no significant interaction between teaching method and student's gender on SS1 mean achievement scores in financial accounting.

Table 5 shows that the F-value on the interaction between teaching method and student's gender on SS1 mean achievement scores in financial accounting is 0.099 which is not significant at 0.754 level of significance; which is greater than 0.05 level of significance set for the study. Therefore, the null hypothesis is not rejected; this means that there is no significant interaction between teaching method and student's gender on SS1 mean achievement scores in financial accounting. 
Table 6: Analysis of Covariance of financial accounting mean retention scores of male and female students in experimental and control groups

\begin{tabular}{lcccccc}
\hline Source & $\begin{array}{c}\text { Type III Sum of } \\
\text { Squares }\end{array}$ & df & Mean Square & F & Sig. & Dec \\
\hline Corrected Model & $7108.783^{\mathrm{a}}$ & 3 & 2369.594 & 47.293 & .000 & \\
Intercept & 350476.765 & 1 & 350476.765 & 6994.912 & .000 & S \\
Group & 5857.613 & 1 & 5857.613 & 116.908 & .000 & NS \\
Gender & 161.278 & 1 & 161.278 & 3.219 & .075 & NS \\
Group & 4.510 & 1 & 4.510 & .090 & .765 & \\
Gender & 8066.829 & 161 & 50.105 & & & \\
Error & 564220.000 & 165 & & & & \\
Total & 15175.612 & 164 & & & &
\end{tabular}

Hypothesis two: There is no significant difference between the financial accounting mean retention scores of SS1 students in the experimental group (cooperative) and control groups.

Table 6 shows that the F-value on the financial accounting mean retention scores of SS1 students in the experimental group (cooperative) and control groups is 116.91 which is significant at 0.000 level of significance, which is less than 0.05 level of significance set for the study. Therefore, the null hypothesis is rejected; this means that there is a significant difference between the financial accounting mean retention scores of SS1 students in the experimental group (cooperative) and control groups.

Hypothesis four: There is no significant difference between the financial accounting mean retention scores of male and female SS1 students in the experimental group (cooperative) and control groups.

Table 6 shows that the F-value on the financial accounting mean retention scores of male and female SS1 students in the experimental group (cooperative) and control groups is 3.219 not significance at 0.075 level of significance, which is greater than 0.05 level of significant set for the study. Therefore, the null hypothesis is not rejected; this means that there is no significant difference between the financial accounting mean retention scores of male and female SS1 students in the experimental group (cooperative) and control groups.

Hypothesis six: There is no significant interaction between teaching method and student's gender on SS1 mean retention scores in financial accounting.

Table 6 shows that the F-value on the interaction effect between teaching method and student's gender on SS1 mean retention scores in financial accounting is 0.090 which is not significant at 0.765 level of significance, which is greater than 0.05 level of significance set for the study. Therefore, the null hypothesis is not rejected; this means that there is no significant interaction between teaching method and student's gender on SS1 mean retention scores in financial accounting.

Summary of the major findings

The result of data analysis has shown that:

1. students taught financial accounting using cooperative teaching method performed better than their counterparts in taught with lecture method.

2. students taught financial accounting using cooperative method retains better than their counterpart taught using lecture method.

3. male students slightly achieved higher than their female, when taught financial accounting using the same method but the difference wasn't significant.

4. male students taught financial accounting using cooperative method retains better than their female counterpart taught using the same method.

5. there is a significant difference between the financial accounting mean achievement scores of SS1 students in the experimental group (cooperative) and control groups.

6. there is a significant difference between the financial accounting mean retention scores of SS1 students in the experimental group (cooperative) and control groups.

7. there is no significant difference between the financial accounting mean achievement scores of male and female SS1 students in the experimental group (cooperative) and control groups.

8. there is no significant difference between the financial accounting mean retention scores of male and female SS1 students in the experimental group (cooperative) and control groups.

9. there is no significant interaction between teaching method and student's gender on SS1 mean achievement scores in financial accounting. 
10. there is no significant interaction between teaching method and student's gender on SS1 mean retention

\section{Discussion of Findings}

$$
\text { scores in financial accounting. }
$$

The result of the study with respect to research question revealed that the experimental group obtained students in experimental group achieved higher than students in control group; hence students taught financial accounting using cooperative teaching method performed better than their counter parts taught with lecture (traditional) method. The findings is in-line with Oyidia (2010) that cooperative method/ activities naturally get students up to interact with their environment.

Data obtained regarding research question two showed that students in the experimental group had higher mean retention score than their counter points in control group. This shows that students taught financial accounting using cooperative method retain better than their counterpart taught using lecture method. The findings is in harmony with $\operatorname{Harb}(2016)$ that retention of learning is measured with the initial test and the delayed retention tests.

Moreover, data obtained regarding research question three revealed that male students in the experimental group slightly achieved higher than their female counterpart but the difference wasn't significant. Again data obtained regarding research question four, showed that male students taught financial accounting using cooperative method retain better than their female counterpart taught using the same method.

This is in agreement with Agboola (2019) that opined males students experience less anxiety about the use of modern technology skills than female students.

The result presented in Table 5 indicated that there was a significant difference between the scores of SS1 students in the experimental group (cooperative) and control groups. Again, the table also revealed that there was no significant difference between the financial accounting mean achievement scores of male and female SS1 students in the experimental group (cooperative and control groups). It further showed that there was no significant interaction between teaching method and student's gender SS1 mean achievement scores in financial accounting. These findings was in line with Emeasoba (2018) that there was no significant difference between the males and females on the effect of cooperative teaching method.

The result presented in table 6, showed that there was no significant difference between the Financial Accounting mean retention scores of males and female SS1 students in the experimental group (cooperative) and control groups. It also revealed that there was no significant interaction between teaching method and student's gender on SS1 mean retention scores in financial accounting.

The findings is in agreement with Emeasoba (2018) that there was no significant difference between the males and females on the effect of cooperative teaching method on student's achievement and retention in Business Education.

\section{Recommendations}

From the findings of the study, the following recommendations are deemed necessary:

1. Financial Accounting teachers should expose their students to the cooperatives method as it encourages interaction and active learning.

2. Financial Accounting teachers should be encouraged to embark on regular training and retraining on the effective use of cooperative learning in the classrooms.

3. The stakeholders especially curriculum planners should advocate for the inclusion of cooperative method in the Financial Accounting curriculum.

4. Post-Primary Schools Management Board (PPSMB) should include cooperative instructional strategies in its regular subject panel workshops.

\section{REFERENCES}

Amadike, O (2014). Effects of interaction patterns on student's achievement And interest in magnetis in Basic electricity in technical colleges in south-south, Nigeria. A Ph.D thesis (unpublished), Department of Technology and Vocational Education, ESUT. 
Anieke, C.U. and Nwankwegu (2019). Enhancing the performance of secondary school students in Agricultural science for food security in Ebonyi State. INTERJ 1(2)113-121. Blg. $17^{\text {th }}$ june.

Browyn, H. (2014). Teaching methods. Retrieved from freeldgetsforyoursite

Emesaoba, N.C. (2018). Effect of cooperative teaching method in office technology and management students achievement in Business Communication selected polytechnics. Unpublished Dissertation (PG) to Department of Vocational Education, Nnamdi Azikwe University, Awka.

Federal Republic of Nigeria (2008). The 9-year Basic Education Curriculum at a Glance: NERDC press: Abuja.

Federal Republic of Nigeria (2014). National Policy on Education (Revised) Abuja: NERDC press.

Ibrahim, R.A. \& R.A. Kazeem, (2015). Essential Financial Accounting for senior secondary schools, Lagos: TONAD publishers Ltd.

Johson, D. and Johnson, R. (2013). Circles of learning (6 $6^{\text {th }}$ ed.). Edina, Minnesota: Interaction Book Company.

Okpe, I.I. (2015). Principles and practice of Book-keeping \& Accounting volume one. Enugu: Chiezugo Ventures.

Oyidiya, K. (2014). Repositioning Administrative and Supervisory Findings in Vocational Education. Unpublished work: Department of Electrical/Electronics, FCE (technical), Omoku.

The West African Examinations Council (2019). Statistics of Results by Grades for all candidates in Enugu State $2017-2020$

Ubesie, M. (2008). Intermediate Financial Accounting. Enugu: Cheston Agency Ltd.

Ugwunwoti, E.P. and Onah, N.G. (2020). Assessment of the implementation on Financial accounting curriculum in senior secondary schools in Enugu Education Zone. British International Journal of Education and Social Sciences.7(8);16-24. 